\title{
A brief note on the sleeping habits of the giant anteater - Myrmecophaga tridactyla Linnaeus (Xenarthra, Myrmecophagidae)
}

\author{
Ísis Meri Medri ${ }^{1} \&$ Guilherme Mourão ${ }^{2}$
}

\author{
${ }^{1}$ Programa de Pós-Graduação em Ecologia, Universidade de Brasília. 70910-900 Brasília, Distrito Federal, Brasil. \\ E-mail: isis@unb.br \\ 2 Laboratório de Fauna, Embrapa Pantanal. Caixa Postal 109, 79320-900 Corumbá, Mato Grosso do Sul, Brasil. \\ E-mail: gui@cpap.embrapa.br
}

\begin{abstract}
The scientific literature on giant anteaters states that the animal sleeps with its tail folded over its body to conserve body temperature. However, observations of this species in natural habitats indicate variations in this behavior, depending on the ambient temperature.

KEY WORDS. Ambient temperature, body temperature, Pantanal.

RESUMO. Breve nota sobre hábitos de dormir do tamanduá-bandeira - Myrmecophaga tridactyla Linnaeus (Xenarthra, Myrmecophagidae). A literatura científica sobre tamanduá-bandeira afirma que o animal dorme com sua cauda dobrada sobre o corpo para conservar a temperatura corporal. Entretanto, observações desta espécie em hábitats naturais indicam variações neste comportamento, dependendo da temperatura ambiente. PALAVRAS CHAVE. Pantanal, temperatura ambiente, temperatura corporal.
\end{abstract}

The giant anteater, Myrmecophaga tridactyla Linnaeus, 1758 (Myrmecophagidae), has a lower body temperature and basal metabolic rate than other vertebrates of the same body mass, which appear to be adaptive responses to its diet of ants and termites, ubiquitous sources of low nutritional quality (EISENBERG 1989). Thus, notwithstanding its large mass, its coat is long to compensate for its very low basal metabolic rate (McNAB 1985). This low metabolism may also explain why the giant anteater, a tropical species, has developed such a heavy, dense coat (SHAw \& CARTER 1980).

The giant anteater uses its hairy tail as a cover when sleeping, folding its bushy tail over its body, especially at low ambient temperatures, to help conserve the body heat generated by its metabolism (ShaW \& CARTER 1980, McNab 1984). This sleeping position also serves to camouflage the sleeping animal (SHAW \& CARTER 1980).

A study was conducted in 2001 in the Pantanal wetlands of the state of Mato Grosso do Sul (18 $\left.{ }^{\circ} 59^{\prime} \mathrm{S}, 056^{\circ} 39^{\prime} \mathrm{W}\right)$, Brazil, involving the capture of giant anteaters, which were outfitted with radio transmitters and then released to monitor their movements and estimate their home ranges (Mourão \& MEdri 2002, MEDRI \& MOURÃo 2005). However, other types of behavior were also recorded and are discussed here.

Giant anteaters do not dig burrows but bivouac in sheltered places, generally dense clumps of shrubs (EISENBERG
1989). The animal generally sleeps in a small cavity it makes with its claws in sandy soil. In the Pantanal, giant anteaters rest mainly in forest patches and savanna, and often forage on grasslands and scrub savanna or use them to move from one type of habitat to another. However, giant anteaters have been seen sleeping in high grass on cooler days. Forest fragments in the Pantanal can provide a safe resting place for giant anteaters because of the presence of dense clumps of spiny bromeliads, Bromelia balansae Mez (Bromeliaceae). Also, temperatures inside forest fragments are usually mild when compared with open habitats (MEDRI \& MOURÃo 2005).

In a large number of sightings $(\mathrm{n}=107)$, giant anteaters were found sleeping with their bushy tails covering their bodies (Fig. 1), even on days when the temperature exceeded $30^{\circ} \mathrm{C}$. However, on June 21, 2001, a particularly cool sunny morning when the ambient temperature was about $17^{\circ} \mathrm{C}$, the giant anteater shown in figure 1 was sleeping with its tail stretched out flat on the ground (Fig. 2), exposing the full length of its body to the sunlight, a behavior that suggests it was using the sun's rays as a source of heat to raise its body temperature.

\section{ACKNOWLEDGEMENTS}

This work was supported by a grant from CNPq - Conselho Nacional de Desenvolvimento Científico e Tecnológico (Brazil) (Process PELD/CNPq \#520056/98-1). Ísis M. Medri held 


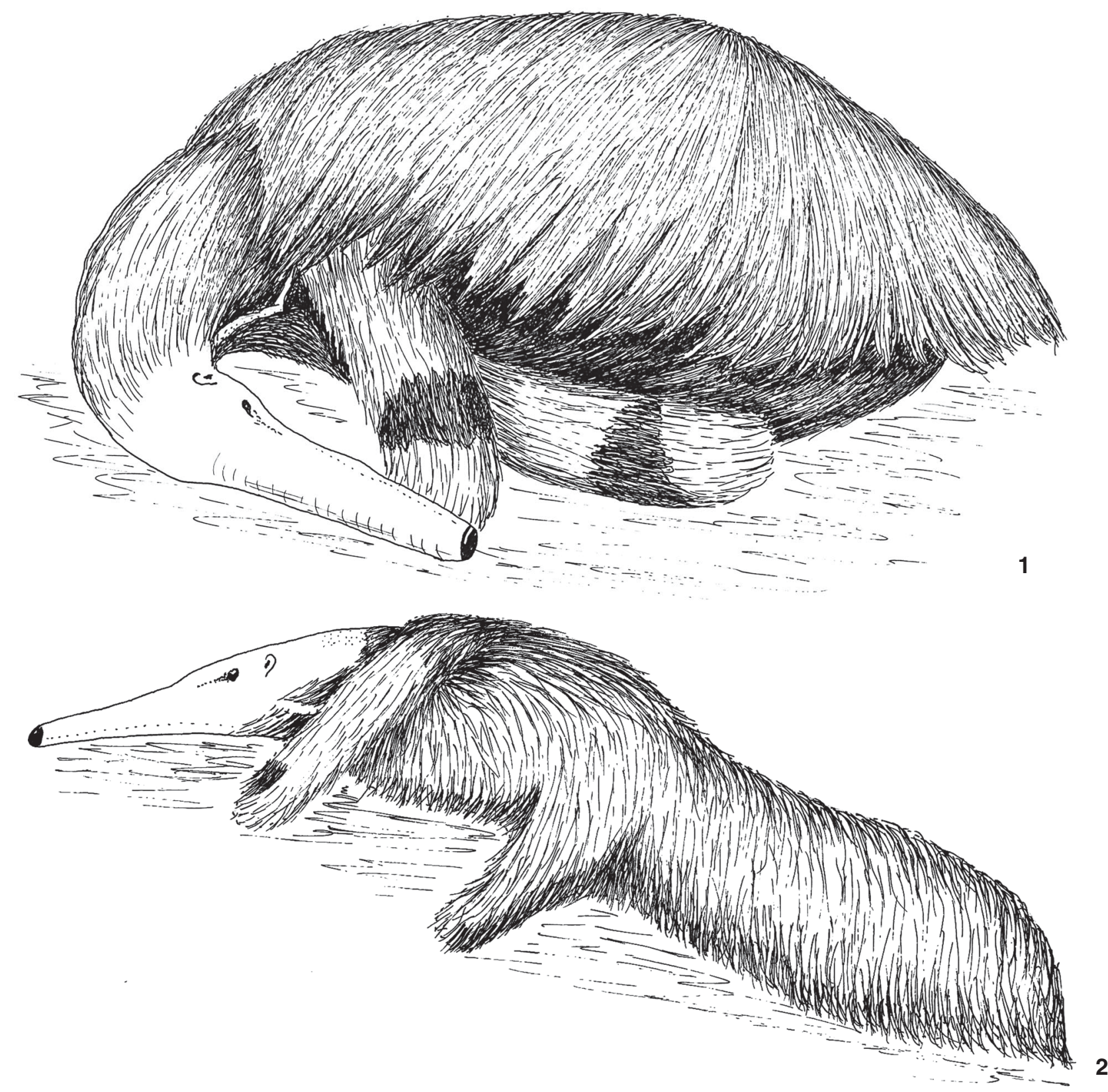

Figures 1-2. (1) Diagrammatic sketch of the giant anteater sleeping with its tail covering its body. This observation was taken on July 24 , 2001 at 9:56 a.m. with ambient temperature of about $28.5^{\circ} \mathrm{C}$, in the Pantanal wetlands of Mato Grosso do Sul State, Brazil; (2) In the Pantanal wetlands of Mato Grosso do Sul State, Brazil, June 21, 2001, early morning with ambient temperature of about $17^{\circ} \mathrm{C}$, giant anteater sleeping with its tail stretched out flat on the ground, suggesting it was using the sun's rays to increase its body temperature.

a scholarship from CAPES - Coordenação de Aperfeiçoamento de Pessoal de Nível Superior (Brazil). We wish to thank "Conservation International do Brasil" and "Embrapa Pantanal" for their logistic support, Henrique de Jesus and Armindo
Gonçalves for their fieldwork, Bèatrice Allain for reviewing the English text, Marcos Antônio dos Santos Silva for the drawings and Gláucia H. F. Seixas for loaning us the radio telemetry equipment used in this research. 


\section{REFERENCES}

Eisenberg, J.F. 1989. Mammals of the Neotropics - The Northern Neotropics. Chicago, University Chicago Press, vol. 1, 449p.

McNAB, B.K. 1984. Physiological convergence amongst anteating and termite-eating mammals. Journal of Zoology, London, 203: 485-510.

MCNAB, B.K. 1985. Energetics, population biology, and distribution of Xenarthrans, living and extinct, p. 219-232. In: G.G. Montgomery (Ed.). The Evolution and Ecology of
Armadillos, Sloths, and Vermilinguas. Washington, Smithsonian Institution Press, 451p.

Medri, Í.M. \& G. MourÃo. 2005. Home ranges of giant anteaters (Myrmecophaga tridactyla) in the Pantanal wetland, Brazil. Journal of Zoology, London, 266: 365-375.

MourÃo, G. \& Í.M. MEDRI. 2002. A new way of using inexpensive large-scale assembled GPS to monitor giant anteaters in short time intervals. Wildlife Society Bulletin, Washington, 30 (4): 1029-1032.

ShaW, J.H. \& E.T.S. Carter. 1980. Giant anteaters. Natural History, New York, 89: 62-67.

Received in 11.III.2005; accepted in 04.XI.2005. 